\title{
Kerklike tug volgens 1 Korintiërs 5 en 6
}

\author{
JJ Engelbrecht \\ Universiteit van Pretoria
}

\begin{abstract}
Ecclesiastical discipline according to 1 Cor $5 \& 6$

According to Paul the believers in Jesus Christ form a community, being in certain aspects completely different from Jews or Gentiles. In order to be what they in principle already are, and for the ultimate benefit of the offenders, ecclesiastical discipline should be applied by this community of believers. The principle is put clear by Paul, but how should it be put into practice in present day circumstances and in each individual case? Do these chapters have any relevance for today's church?
\end{abstract}

\section{INLEIDING}

Mislukte huwelike en egskeidings kom selfs in die geledere van kerklike ampsdraers al hoe meer voor; seksuele praktyke wat tradisioneel as ongeoorloof in Christelike kringe beskou is, word skynbaar in toenemende mate as normaal en dus as geoorloof beoefen en beoordeel deur sekere kerkmense.

Kerkmense wat mekaar dagvaar, soms juis oor dinge wat op kerklike terrein gebeur het, is ook nie 'n heeltemal onbekende saak in ons kerklike lewe in die Republiek van Suid-Afrika nie.

In kerklike kringe word op hierdie verskynsel onder andere op twee teenoorgestelde wyses gereageer: Die een groep beskou kerklike tug as 'n verouderde en uitgediende praktyk, onder andere 'omdat ons tog maar almal sondaars is en dit lewenslank sal bly'.

Die ander groep pleit vir verskerpte kerklike tug, maar sonder toepassing van die uiterste tugmaatreël. Met laasgenoemde maatreël word bedoel die uitsluiting uit die gemeenskap van die gelowiges, met behulp van die kerklike ban. Ander bepleit en beoefen selfs op 'n relatief groot skaal die praktyk van die kerklike ban, om van die 'vroeëre' stadia van die kerlike tug nie eers te praat nie. 
Genoemde verskynsels was die stimulus om onder andere noukeuriger te gaan kyk na 'n Nuwe Testamentiese gedeelte soos 1 Korintiërs 5 en 6 . Natuurlik is dit nie die enigste deel van die Nuwe Testament of van die Bybel wat in 'n debat oor kerklike tug ter sake is nie, maar as deel van die KANON van die Nuwe Testament, kan dit beslis nie by voorbaat oorgeslaan word nie.

Vervolgens word veral aan die volgende aspekte van 1 Korintiërs 5 en 6 aandag geskenk:

- Die aanleiding tot Paulus se betoog

- Die vraag wat en wie volgens Paulus tugwaardig is

- Die vorm van tug wat deur Paulus voorgestaan word

-Wie moet die tug uitoefen?

- Die doel en effek van die tug

- Die rol van die oortreder se gesindheid.

\section{DIE AANLEIDING TOT PAULUS SE BETOOG}

In die opbou van hierdie Paulusbrief is daar nie 'n duidelike en logiese oorgang vanaf die vorige hoofstukke na die betrokke twee hoofstukke nie (vgl Bruce 1980: 53; Fascher 1975: 155). Conzelmann (1979: 115) wys wel op wat hy as moontlike raakpunte beskou wanneer hy vra of daar nie uit die tema logos van hoofstukke een tot vier en die tema bios van hoofstukke vyf en ses 'n einheitliche houding in Korinte blyk en waarteen Paulus stry nie. Sy vermoede word versterk deurdat volgens 5: 9v, die tema van ropveía reeds in 'n vroeëre brief bespreek is. Nou moet Paulus die verbod op ropvei $\alpha$ in 'n praktiese situasie toepas en tegelykertyd voorkom dat dié gebod in 'n asketiese beginsel verander.

Waar Paulus wat vermoedelik van Efese af skrywe (vgl 1 Kor 16: 8; Guthrie 1974: 442; Lategan 1984: 64), aan sy inligting oor die wanpraktyke in die gemeente kom, word nie gesê nie.

Vermoedelik het dit op mondelinge oorlewering berus (vgl 11: 18), maar die informant(e) is onbekend (Conzelmann 1979: 115).

Dat hierdie twee hoofstukke werklik deel vorm van wat in die kanon van die Nuwe Testament bekend staan as 1 Korintiërs, word algemeen aanvaar (Kümmel 1973: 238; Lategan 1984: 76v; Richardson 1983: 41-43). Die problematiek van hierdie hoofstukke kan dus nie so maklik omseil word deur te beweer dat dit nie deel van die brief vorm of dat dit nie Paulinies is nie!

Die eerste geval wat in hoofstuk vyf ter sprake kom, is die van 'n manlike lidmaat van die gemeente wat vir hom iemand as vrou geneem het met wie sy pa 
destyds nog steeds getroud was of tevore getroud was (5: 1-13). Vervolgens skenk Paulus aandag aan die verskynsel dat lidmate van die gemeente nie alleen oor

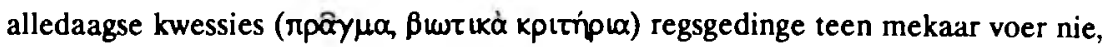
maar, erger nog, daarmee na heidense regters gaan om oor geskille tussen kerkmense te beslis (6: 1-11). Richardson (1983: 37) meen dat dit in hierdie geskille oor seksuele kwessies handel. Daaraan word later aandag geskenk.

Dan volg 'n betoog en oproep met die strekking dat die Christene in Korinte God in hulle liggame moet verheerlik. Dít impliseer dat hulle nie aan seksuele losbandigheid of enigiets anders mag deelneem wat nie te rym is met die feit dat elkeen van hulle se liggaam 'n tempel van die Heilige Gees is en dat hulle nie aan hulleself behoort nie (6: 12-20).

\section{WAT EN WIE IS TUGWAARDIG?}

Klaarblyklik kan Paulus en die res van die gemeente slegs oor mede-kerkmense oordeel, mense wat deel vorm van die Christelike gemeente (5: 12-13). Die oordeel oor mense buite die gemeente sal deur God gehanteer word (5: 12-13). Dit is vermoedelik ook die rede waarom Paulus niks sâ oor tughandelinge teenoor die vrou wat in hoofstuk vyf ter sprake kom nie. Tog skryf Paulus elders dat ons 'almal voor die regterstoel van Christus (moet) verskyn, sodat elkeen kan ontvang volgens wat hy tydens sy aardse lewe gedoen het, of dit nou goed was of kwaad' ( 2 Kor 5 : 10). Sou laasgenoemde stelling dalk impliseer dat die tug of oordeel van die gemeente nie finaal is nie? Vermoedelik is dit die bedoeling. Die fmale beslissing ook oor die lot van die kerkmens wat die spoor byster geraak het, berus by Christus.

Die man is lidmaat van die gemeente en as sodanig is hy aanspreeklik vir sy optrede (2 Kor 5: 1-13). Hierdie man en 'n vrou met wie sy pa nog steeds of tevore getroud was, het soos man en vrou saam geleef $(5: 1)$. Of sy pa reeds oorlede was, geskei was van die vrou of dalk nog met haar getroud was, word nie gese nie.

Volgens Paulus is hierdie man en vrou se optrede ' $n$ vorm van onsedelikheid ( verstaan moet word of hoe feitlik korrek Pavlus se stelling is, is nie so'n uitgemaakte saak nie: Conzelmann (1969: 116) stel dat sowel die Joodse as die Romeinse reg 'n huwelik tussen 'n stiefmoeder en 'n stiefseun verbied, om nie eers te praat van 'n huwelik tussen 'n kind en sy eie moeder nie (vgl Lev 18: 7; Gen 35: 22; $49: 4$ en ander literatuur waarna Conzelmann (1969: 116) verwys. Fascher (1975: 157) daarenteen, beroep hom op Strack-Billerbeck vir sy stelling dat die meeste Joodse geleerdes geen beswaar gehad het teen die huwelik van 'n heiden of 'n proseliet met sy stiefmoeder nie. Syns insiens het hierdie houding daartoe meegewerk dat die 
Christelike gemeente in Korinte so lou en slap was in hul houding teenoor oortreders in hul midde:

Will man die Entrüstung des Paulus und sein Urteil, so etwas käme nicht einmal unter Heiden vor, recht erschätzen, so muss es sich um ein Verhältnis des Sohnes zur Stiefmutter noch zu lebzeiten des Vaters handeln, so dass hier weder bei Heiden noch bei Juden eine mildere Rechtspraxis zu erwarten ist, da Bigamie bei beiden Gruppen verboten ist.

As Fascher gelyk het, beteken dit dat die vrou van 1 Korintiërs 5 aan bigamie skuldig was.

Dit trek aandag dat hoewel Paulus as Joodse teoloog sekerlik goed onderlê was in die Joodse halaka, hy hoegenaamd nie daarna verwys wanneer hy hier oor etiese kwessies standpunt inneem nie (vgl Fascher 1975: 157; Lindemann: 1986: 246-265, veral 247, 261-265); trouens, hoewel Paulus elders in sy briewe hom herhaaldelik beroep op Bybeltekste om te bewys dat daar 'n ooreenstemming bestaan tussen die evangelie wat hy verkondig en die belofte van God, verstaan hy die Ou Testament nie meer as Tora in eintlike sin nie: Paulus vel sy etiese beslissinge veel meer vanuit sy geloof in Christus; dit vloei vir hom uit die evangelie voort (vgl Lindemann 1986: 263-265). Volgens 5: 3 vel hy sonder enige verwysing na 'n Skrifgedeelte of die halaka, met apostoliese gesag 'n skerp oordeel oor die oortreder. Daarmee word egter nie ontken dat Paulus in sy etiek oor die algemeen ook in 'n mate van tradisies gebruik maak nie (vgl Wendland 1970: 50; Sanders 1975: 65-66).

Dit is belangrik om raak te sien dat nie net hierdie spesifieke vorm van seksuele

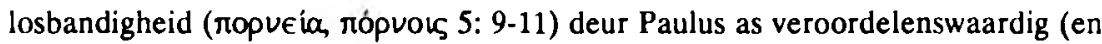
dus tugwaardig?) beskou word nie; so ook nie slegs seksuele losbandigheid nie. Volgens 5: 11 (vgl ook 5: 9-10) mag die gemeentelede nie 'omgaan met iemand wat homself 'n gelowige noem, maar wat onsedelik of geldgierig of ' $n$ afgodsdienaar of kwaadprater of dronkaard of bedrieër is nie. Met so iemand mag (hulle) nie eens saam eet nie'.

Hierdie sondelyste, net soos die lyste van deugde wat elders in die Nuwe Testament aangetref word, is nie bedoel as volledige katalogi nie, maar slegs as 'n paar voorbeelde, miskien voorbeelde van die ergste sondes of die wat die meeste voorgekom het (Conzelmann 1969: 121-123 met voetnotas; Mark 7: 21vv; Rom 1: 29-31; 13: 13; 2 Kor 12: 20-21; 6-7; Ef 4: 2-3; 2 Pet 1: 5-7 ens). 
'n Paar belangrike vrae wat nou opduik, is die volgende:

Bedoel Paulus met die porneia (ropvel $\alpha$ ) net die uiterste vorm van seksuele losbandigheid, of sluit dit die voorstadiums' soos gedagtes en begeertes in, soos dit byvoorbeeld die geval is in Romeine 7: 7?

Ook van mense wat aan ander sondes as seksuele losbandigheid skuldig is, geld dat die gemeentelede selfs nie eens saam met hulle mag eet nie (1 Kor 5: 11). Tog lyk dit of die onsedelikheid (ropveía) in 'n nog ernstiger lig beskou word as die ander vorms van sonde, omdat Paulus se dat 'elke ander sonde wat 'n mens doen, ... buite sy liggaam plaas(vind), maar (dat) iemand wat seksueel losbandig lewe (ropveúwv), ... hom (vergryp) aan sy eie liggaam ( $\epsilon$ ls tò tô.

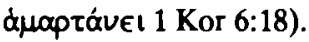

Wat sou Paulus met hierdie onderskeiding bedoel en waarop sou hy dit fundeer? Word vir die seksuele vergrype enersyds en die ander sondes andersyds verskillende vorme of grade van tug verwag?

Op die vraag of Paulus met 'onsedelikheid' (ropveía) net die uiterste vorm van seksuele losbandigheid bedoel, moet hoogs waarskynlik 'nee' geantwoord word. Die uiterste vorm sou seker die beoefening van geslagsgemeenskap wees met enigeen wat geïnteresseerd is teen betaling of nie. Dit lyk nie of dit is waaraan die man of die vrou in 1 Korintiërs vyf skuldig is nie. Volgens die Greek-English Lexicon van Nida en Louw (1988), gaan dit in die Nuwe Testament by die betrokke selfstandige

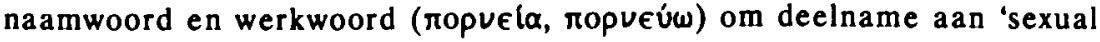
immorality of any kind, often with the implication of prostitution'.

Romeine 7: 7 is 'n voorbeeld waaruit blyk dat Paulus, blykbaar met 'n beroep op die tiende gebod, minstens in dárdie konteks reeds die ongeoorloofde begeerte na die vrou van 'n ander man, as sonde beskou. Conzelmann (1969: 197) stel dat die ganse wet hier saamgevat word in die verbod op die begeerte. Daar is geen goeie rede om te veronderstel dat hy in 1 Korintiërs 5 en 6 die 'eerste stadium' van onsedelikheid, naamlik die gesindheid, die begeerte na 'n ongeoorloofde verhouding, uitgesluit het van sy veroorde ling nie. Maar reeds in 1 Korintiërs 10: 6 word

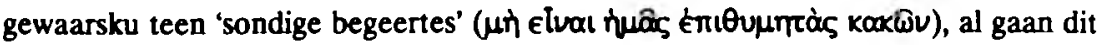
daar miskien nie uitsluitlik of primer por ongeoorloofde seksuele begeertes nie, maar ook oor afgodediens (vgl Conzelmann 1969: 197). 
Wanneer Paulus waarsku teen die vergryp of sonde teen jou eie liggaam, is dit nie so eenvoudig om vas te stel wat hy met die term liggaam bedoel nie. Verder is dit ook nie so duidelik hoe die liggaam $(\sigma \omega \hat{\omega} \mu \alpha)$ en vlees $(\sigma \alpha ́ p \xi)$ in hoofstuk ses

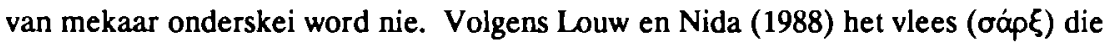
volgende betekenismoontlikhede: 'flesh, body, people, human, nation, human nature, physical nature, life'.

Liggaam $(\sigma \widehat{\omega} \mu \alpha)$ het op sy beurt volgens genoemde outeurs die volgende betekenismoontlikhede: 'body, physical being, church, slave, reality'.

In 1 Korintiërs 15: 50, dus in dieselfde brief, word gestel dat 'vlees ( $\sigma \alpha ́ p \xi)$ en bloed ... nie aan die koninkryk van God (kan) deel kry nie' en volgens 15: 44 word 'n natuurlike liggaam $(\sigma \omega \hat{\omega} \mu)$ gesaai wanneer 'n gelowige mens te sterwe kom. In albei gevalle gaan dit dus om iets wat sterf en vergaan (vgl ook 15: 35, 39-41). Daarteenoor word 'n geestelike liggaam ( $\sigma \omega \hat{\omega} \mu \alpha$ wuxukóv) opgewek (15: 44). Daar kan dus nie sonder meer gesê word dat die vlees dui op die sterflike aspek van mens wees, terwyl die liggaam dan sou dui op die nuwe en onsterflikc aspek van menswees nie. Die nuutheid of nuwe situasie waarin die Christengelowiges verkeer, kom in 1 Korintiërs vyf en ses onder andere daarin tot uitdrukking dat hulle 'nuwe, ongesuurde deeg' is (5: 6), dat hulle hul 'sonde laat afwas' het, dat hulle 'geheilig' en 'vrygespreek' is 'in die Naam van die Here Jesus Christus en deur die Gees van God' (6: 11). Verder ook daarin dat hulle liggaam 'deel is van Christus' (6: 15) en hulle dus geestelik een is met Hom (6:17). Boonop is hulle liggaam 'n tempel waarin die Heilige Gees woon, behoort hul nie aan hulleself nie en moet hulle God dus in hulle liggaam verheerlik (6: 19-20).

Volgens Minear (1983: 347) identifiseer Paulus se teenstanders vlees en liggaam, sodat hulle aan die een net so min waarde heg as aan die ander. Minear dink hier vermoedelik aan die teenstanders wat volgens 1 Korintiërs 15 die opstanding van die dooies ontken het. Daarmee sou dan saamgaan 'n 'gnostiese' minagting van die liggaam en die dinge wat met die liggaam gedoen word (Minear 1983: 347).

Anders as sy teenstanders wat vlees en liggaam identifiseer en as onbelangrik beskou, onderskei Paulus tussen vlees ( $\sigma \dot{\alpha} p \xi)$ en liggaam ( $\sigma \omega \hat{\omega} \mu \alpha)$ en konsentreer dan op die liggaam. Die liggaam van die gelowige het radikaal 'verander' in vergelyking met die situasie voordat die betrokke persoon 'n Christengelowige geword het. As die gelowige egter nie lig loop nie, kan hy lelik terugval in 'n toestand wat permanent agter die rug moes gebly het:

To the extent that self and body were inseparable, to that extent their body had moved from the world to the kingdom. When they denied 
this transfer, the flesh became again the property of Satan, part and parcel of the world (Minear 1983: 347).

Byrne (1983: 610-612) sê dat hy Paulus se gebruik van liggaam ( $\sigma \omega \mu \alpha)$ verstaan soos Kăsemann en huldig die standpunt dat

The essence of soma for Paul lies in being the vehicle of communication, so that Paul can conceive of a mode of communication - of presenting oneself and being acted upon in turn - that is very different from present physical existence but which remains, nonetheless, somatic existence.... (1 Cor 15: 35-49).... In the passage we are considering (1 Cor 6: 12-20) soma is in this sense factually and concretely identifiable with the physical body. The latter, Paul insists, retains full theological and moral significance. Not only must it be preserved from misuse, as in fornication. It can and should be positively an instrument for the glorification of God (20b v).

Bogenoemde interpretasie wat Byrne van Paulus se gebruik van die term liggaam gee, is verhelderend en aanvaarbaar. Tog wil ons die vraag vra of daar nie nog meer reg aan die teks sal geskied as by die interpretasie van die gebruik van liggaam $(\sigma \widehat{\omega} \mu \alpha)$ in 1 Korintiërs vyf en ses, rekening gehou word met die dialektiek wat in ander opsigte ook so'n belangrike rol in Paulus se teologie speel nie. Die dialektiek naamlik van alreeds en nog nie of die verhouding tussen die indikatief en imperatief (vgl Coetzee 1984: 238-239; 249-251; Lategan 1984: 323-324). Enersyds is die liggaam van die Christengelowige reeds nuut, 'n tempel van die Heilige Gees, andersyds is dit in hierdie lewe nog steeds 'n sterflike liggaam, vlees ( $\sigma a ́ p \xi)$, nie geskik vir die koninkryk van die hemele nie.

\subsection{Sonde teen die eie liggaam}

Maar in watter opsig is onsedelikheid, anders as ander sondes, 'n vergryp teen die

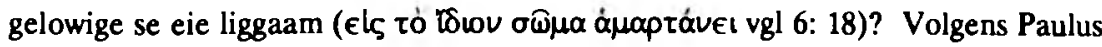
het die gelowige se liggaam danksy sy verbintenis met Christus, nuut geword, al is dit dan slegs 'n geloofswerklikheid wat nie fisies waarneembaar is nie (ons onderskeiding. Paulus gebruik nie hierdie terme nie). Hierdie liggaam is 'n tempel van die Heilige Gees (6: 19-20) waarin God verheerlik moet word (6: 20); hierdie liggaam is deel van Christus en dit mag nie deur omgang met 'n ontugtige vrou, deel van haar gemaak word nie (6: 15-17). 
Paulus se redenasies kan nie altyd konsekwent deurgevoer word nie, soos blyk uit sy redenasie oor die gelowige se een wees met Christus wat dit in beginsel onmoontlik maak om met 'n los vrou een te wees. Tog het Paulus geen beswaar teen die een word van 'n gelowige egpaar met mekaar nie (1 Kor 7: 5). Dit word blykbaar nie deur hom beskou as in teenspaak met die gelowige se een wees met Christus nie. Was dit Luther wat gesê het dat alle konsekwensie na die duiwel lei?

Wanneer met hierdie vrae geworstel word, moet toegegee word dat Minear (1983: 341) in 'n groot mate gelyk het wanneer hy beweer dat ons hierdie twee hoofstukke nie kan verstaan nie.

\subsection{Homoseksualiste}

Wat betref die seksuele sondes wat by die naam genoem word, word hier nou nog net oor 'mense wat homoseksualiteit beoefen' ( $\mu \alpha \lambda \alpha$ kol en ápoєvokoîta! 6: 9) enkele opmerkings gemaak. In hierdie konteks is die $\mu \alpha \lambda \alpha$ koì waarskynlik die passiewe manlike deelnemers aan homoseksuele omgang, terwyl die ápбєvokoî $\alpha$ die aktiewe manlike deelnemers is.

In die Pauliniese literatuur word homoseksualietit of dan ten minste bepaalde aspekte daarvan, verbied (Rom 1: 26; 1 Kor 6: 9; 1 Tim 1: 10). Die teologiese debat oor die vraag of eties onderskei moet word tussen homofilie wat yolgens sommige aanvaarbaar sou wees en homoseksuele prostitusie wat veroordeel word, is nog lewendig aan die gang (vgl Labuschagne 1970: 55-65; Wright 1984: 125-153; Ukleja 1983: 350-358). In hierdie debat word onder andere beweer dat die Nuwe Testament slegs homoseksuele prostitusie veroordeel, terwyl ander meen dat homoseksuele teoloë meer bekommerd is oor aanvaarding deur die samelewing as oor die eise van Gods Woord.

\subsection{Hofsake tussen gelowiges}

In 6: 1-11 word gehandel oor die verskynsel dat gemeentelede nie alleen oor alledaagse dinge ( $\beta \omega \tau \tau$ Kk $\dot{\alpha})$ regsgedinge teen mekaar het nie, maar dat hulle boonop daarmee na heidense regters gaan. In die lig van die gemeente se eskatologiese

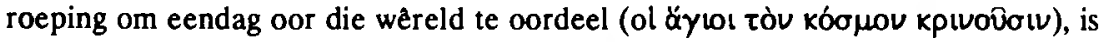
dit vir Paulus totaal onaanvaarbaar dat hulle met onderlinge geskille gaan hulp soek

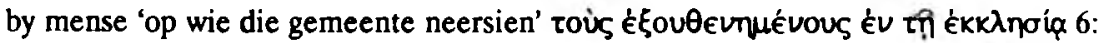

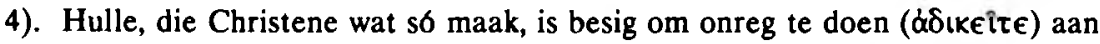
medegelowiges. Verder: Mense wat onreg doen sal geen deel kry aan die koninkryk van God nie (6: 8-9). Met hulle sal dit net so gaan soos met die onsedelikes, 
afgodsdienaars, egbrekers, die mense wat homoseksualiteit beoefen, ensovoorts (6: 9-10). Dit moenie uit die oog verloor word dat hulle reeds skuldig is deurdat hulle hoegenaamd as Christene onderlinge regsgedinge het nie (6: 7).

In 'n lesenswaardige artikel probeer Peter Richardson (1983: 37-58) aantoon dat die hele hoofstuk vyf en ses, 6: 1-11 ingesluit, oor seksuele vrae handel. Hy gee toe dat nêrens in die betrokke twee hoofstukke gesê word waaroor die hofsake gaan nie en dat die navorser vir inligting daaroor, dus afhanklik is van leidrade onder die oppervlakte. Sy argumente is nie heeltemal oortuigend nie, omdat 'n betoog oor regsgedinge (sonder seksuele konnotasies) ons insiens nie so'n Fremdkörper in hierdie hoofstukke hoef te wees nie: Die raakvlakke met die res van hierdie twee hoofstukke kan ook wees die prinsipiële andersheid van die Christelike gemeente in vergelyking met hulle omgewing - Nie noodwendig net wat seksuele norme betref nie (vgl 5: 7v, 11).

Hier word nie nou verder in besonderhede ingegaan op die ander sondes wat in die betrokke hoofstukke genoem word nie, maar dit behoort uit wat reeds gesê is, duidelik te wees dat dit nie net seksuele losbandigheid is wat deur Paulus as onversoenbaar met 'n Christelike lewe beskou word nie: Die Christene moet ook gemeentelede wat geldgieriges, afgodsdienaars, kwaadpraters, dronkaards en bedrieërs is, vermy (vgl 5: 9-12). Egbrekers en mense wat homoseksualiteit beoefen, sal geen deel kry aan die koninkryk van God nie, maar so ook die diewe, geldgieriges, dronkaards, kwaadpraters, bedrieërs en mense wat onreg doen (vgl 6: 9v)!

Tog is daar vir hulle almal sonder uitsondering hoop: As hulle hul sonde laat afwas, as hulle geheilig word, as hulle vrygespreek word 'in die Naam van die Here Jesus Christus en deur die Gees van ons God' (6: 11).

Enersyds lyk dit of die onsedelikheid (ropvei $\alpha$ ) as sonde teen die eie liggaam (6: 18) skerper veroordeel word as ander sondes, maar andersyds sluit ook dronkenskap en kwaadpratery die beoefenaar daarvan uit die koninkryk van God uit - En wat kan volgens hierdie hoofstukke en volgens die res van die Pauliniese literatuur erger wees as dit?

Aan die vraag of daar (om praktiese redes?) van kerklike weë teen oortreders op seksuele terrein ernstiger tugmaatreëls getref moet word as teen oortreders op ander terreine, sal later aandag geskenk moet word.

\section{WATTER VORM VAN TUG STAAN PAULUS VOOR?}

Die antwoord op bogenoemde vraag is nie so eenvoudig nie. Volgens 5: 2 moes die gemeente klaarblyklik oor die vergrype van die oortreder 'getreur' en hom so uit 
hulle kring verwyder het. In die lig van 5: 3-4, lyk dit of hierdie 'treur' wat Paulus in gedagte het, nie net 'n emosie is nie, maar beslis ook 'n oordeel en 'n groepshandeling om daardie oordeel tot uitdrukking te bring: Hulle sou daardie oortreder aan die Satan oorgee. Hoe moet hierdie handeling voorgestel moet word?

Weiss (1925: 129v) meen dat die verwydering uit die gemeente die eerste waarneembare effek van die oordeel is, soos syns insiens duidelik uit verse 7 en 13 blyk. Dít is egter slegs die sigbare kant van 'n gebeure op die terrein van die Geisterwelt. Hier word volgens Weiss gewerk met die oortuiging dat die uitspraak

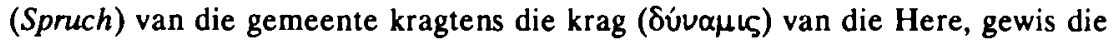
gevolg sal hê dat die veroordeelde aan die Satan oorgegee sal word. Vir Paulus en die Korintiërs was die Satan en sy mag 'n realiteit (vir die NT demonologie, vgl Van Aarde 1986: 547-563).

Die nuwe, Christelike gemeenskap, het tot stand gekom danksy die feit dat die Satan deur Jesus Christus oorwin is (1 Kor 15: 24-27; Fil 2: 10v; Kol2: 15). Wie uitgesluit is uit die sfeer waarin Christus in 'n besondere sin werk, is dus teruggewerp in die sfeer waarin die Satan nog in 'n beperkte sin heerskappy voer. Die veronderstelling is minstens dat die 'oorgelewerde' sal ly (vgl Hand 13: 11) en moontlik dat hy sal sterf (vgl Hand 5: 5,10; 1 Kor 11: 30; Barrett 1976: 126v; Conzelmann 1969: 118, met verwysings na 11: 30; Wendland 1968: 43).

Barrett (1976: 127) hou ook rekening met die moontlikheid dat die bedoeling gewoonweg kan wees 'that ... man's essential self will be saved with the loss not only of his work but of his flesh.'

Klaarblyklik is die gedagte dat hierdie verwydering van die oortreder uit die geledere van die gemeente, moet geskied in die Naam van die Here Jesus en dat sy krag daarvoor nodig is. Dit lyk of die gemeente bymekaar moet kom, dat die apostel in die gees teenwoordig sou wees by die byeenkoms, dat hulle die hulp van die Here Jesus in die gebed moet afsmeek en vervolgens by wyse van ' $n$ formele besluit die oortreder aan die Satan moet oorgee (5: 3-4). Die veronderstelling is blykbaar dat hy sal sterf (vgl 'so sou sy sondige aard vernietig word...' 5: 5; De Boor 1968: 85v; Pop 1971: 102-104).

Gedagtig aan die feit dat nóg die Jode nóg die Christene as inwoners en onderdane van die Romeinse Ryk die reg gehad het om doodvonnisse in watter vorm ookal te voltrek, kan die moontlikheid dat die gemeente so 'n getugtigde moet teregstel, uitgesluit word (vgl Bruce 1980: 55). Paulus dink waarskynlik aan een of ander kragtige bomenslike ingryping soos byvoorbeeld die dood van Ananias en Saffira (Hand 5: 1-11: vgl Wendland 1968: 44) of die wurms wat Herodes Agrippa 1 verteer het (Hand 12: 23). 
'n Ander vorm van tug wat in hierdie twee hoofstukke ter sprake kom, is dat die gemeente nie moet omgaan ( $\sigma v v \alpha v a \mu i y v v \sigma \theta \alpha$ ) met iemand wat homself 'n gelowige noem, maar aan sekere vergrype skuldig is nie. 'Met so iemand moet (hulle)

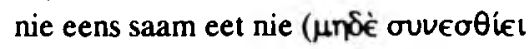

v 5: 11).

Dit kan nie met sekerheid vasgestel word of dit hier net om 'n verbod op deelname aan die nagmaal gaan of selfs om gewone maaltye nie. Volgens Barrett (1976: 132) gaan dit sowel om uitsluiting van die nagmaal as van privaat maaltye. So ook Conzelmann (1969: 123).

\section{WIE MOET DIE TUG UITOEFEN? HET HULIE 'N KEUSE?}

Soos reeds gesê, laat Paulus in hierdie twee hoofstukke geen twyfel daaroor dat hy as apostel die gesag en verantwoordelikheid het om hom met die tughandeling besig te hou nie, maar dit is net so duidelik dat hy veronderstel dat dit nie sy alleenreg-of plig is nie: Die gemeente moet ook vergader en 'n besluit neem, terwyl die tug in die Naam van die Here Jesus en met sy krag moet geskied (S: 3v; Barrett 1976: 124).

Of en hoe dit sal blyk dat dit met die krag van die Here Jesus geskied, kan slegs vermoed word. Onder die vorige punt is reeds een hipotese hieroor genoem.

Nog Paulus, nog die gemeente het 'n keuse of hulle die tug wil uitoefen of nie: Danksy die dood van Jesus Christus, is die gemeente reeds 'nuwe, ongesuurde deeg' (5: 7; vgl 6: 11, 18-20), en daar word doodeenvoudig van hulle verwag om te wees wat hulle in Christus reeds is. Dit impliseer onder andere dat hulle 'die ou suurdeeg' verwyder (5: 7), dat hulle 'treur' oor die wanpraktyk in hulle midde (5: 1 4,11-13).

\section{DIE DOEL EN EFFEK VAN DIE TUG}

As die tug die verwydering van die ou suurdeeg, die verwydering van die slegte mens uit die midde van die gemeente is, is die onmiddellike doel wat die getugtigde betref, dat 'sy sondige aard vernietig word' ( $5: 5$ ), maar die langtermyn doel is dat 'sy gees gered kan word op die dag wanneer die Here kom' (5: 5). Wat die besonderhede betref is dit uiters moeilik om vas te stel wat Paulus hier bedoel, maar wat wel duidelik is, is dat die doel met die tug nie is om die getugtigde finaal verlore te laat gaan nie, maar juis om hom uiteindelik te behou met die wederkoms.

Vir die gemeente hou die tug die voordeel in dat dit 'n verderwende invloed wat die hele gemeente kon laat skade ly, uit hulle midde verwyder (5: 6).

In hierdie konteks is daar geen sprake van dat die kerk 'n corpus permixtum is in 
die sin dat onkruid en koring maar tot met die oes deurmekaar op die land moet staan om dan eers van mekaar geskei te word nie (vgl Matt 13: 30; 1 Kor 5: 6-8, 13; 6: 11, 19v). Tog is die blote feit dat die apostel die gemeente moet aanspreek soos hy dit doen, ' $n$ aanduiding dat hulle beslis nie ' $n$ idilliese klomp Christene was vir wie die stryd teen die sonde finaal agter die rug gelê het nie. Hulle was nog glad nie bevry van die worsteling om te wees wat hulle in beginsel reeds was nie (5: 7).

\section{IS DAAR RUIMTE VIR 'N GESINDHEIDSVERANDERING BY DIE OORTREDER?}

In die lig van 6: 11 en 2 Korintiërs 2, moet seker veronderstel word dat as die nodige gesindheidsverandering by die oortreder sou plaasvind, die tughandeling nie uitgevoer sou word nie (vgl Fascher 1975: 161).

\section{SLOTOPMERKINGS}

Dit blyk dat daar oor die wyse van tuguitoefening in Korinte nie baie duidelikheid bestaan nie. Dit moet aanvaar word dat daar nog nie vaste voorskrifte en vorme in hierdie verband bestaan het nie.

Dit is ook nie duidelik waarom Paulus soos iemand dit gestel het, hier nie met ink skryf nie, maar met gal, terwyl hy in 2 Korintiërs 'n veel milder toon aanslaan nie.

Wat egter wel duidelik is, is dat hy uitgaan van die veronderstelling dat die Christene van eienaar verwissel het. Hulle behoort nou aan Iemand anders. Hulle is nie meer heidene nie, en dit het konsekwensies ook vir hulle gesindheid en optrede teenoor mekaar en tenoor ander mense.

Verder: Dit is nie die individuele gemeentelid se eie saak hoe hy wil lewe nie en dit is ook nie net 'n saak tussen hom en die Here nie: Die gemeente word as groep daarvoor verantwoordelik gehou dat daar iets aan die saak en dus aan die oortreder gedoen sal word. Dit is in belang van die oortreder en in belang van die gemeente as geheel. Niemand mag die indruk kry dat die oortreder se optrede goedgekeur word nie.

Hierdie hoofstukke bring aan die lig dat volgens Paulus veel meer as net seksuele sondes die welwese van die gemeente bedreig en dat teen alle sondes gestry moet word. Daarteenoor word nie presiese voorskrifte gegee oor hoe in elke individuele geval opgetree moet word nie. Met hierdie stelling word nie bedoel om die erns van seksuele sondes af te water nie, maar word daarop gewys dat die erns van die ander sondes nie onderskat moet word nie. Kan uit die konteks afgelei 
word dat in elke geval ander of strenger tugmaatreëls ten opsigte van seksuele sondes getref moet word as ten opsigte van die ander genoemde sondes?

In verband met regsgedinge waarmee Christene met mekaar hof toe gaan, sal in die hede ook daarmee rekening gehou moet word dat baie landdroste en regters in die RSA self Christengelowiges is. Dit sou dus nie korrek wees om te sê dat hulle 'heidense regters' (vgl 6:1) is nie.

Oor die rol van die prediking, kategese en pastoraat as (moontlike) aspekte van kerklike tug, word in die bestudeerde gedeelte niks gesê nie.

'n Kerklike praktyk in die hede waar mense links en regs met behulp van 'n kerklike banformulier uit die koninkryk uitgesluit word (as die aanspraak wat in die formulier gemaak word gefundeerd is) en dit boonop meermale oor randsake, kan sekerlik nie gesteun word met 'n beroep op 1 Korintiërs 5 en 6 ses nie (vgl De Boor 1968: 100).

Wanneer in die hede (vgl Patte 1984: 9, 11) besluit moet word oor die wyse van tug wat in 'n bepaalde geval toegepas moet word, sal in 'n kerk waarin die Bybel as kanoniek aanvaar word, vanselfsprekend ook na al die ander Bybelse gegewens wat ter sake is gekyk moet word.

\section{Literatuurverwysings}

BARRETT, CK 1976. The first epistle to the Corinthians. 2nd ed repr. London: Black (Black's NT Commentaries.)

BRUCE, FF 1980. 1 \& 11 Corinthians. London: Eerdmans (NCB.)

BYRNE, SJ 1983. Sinning against one's own body: Paul's understanding of the sexual relationship in 1 Corinthians 6: 18. $C B Q 45 / 1,608-616$.

COETZEE, JC 1984. Die Heilige Gees in die prediking van Paulus, in Du Toit 1984: 234-255.

CONZELMANN, H 1969. Der erste Brief an die Korinther. Göttingen: Vandenhoeck.

DE BOOR, Werner 1968. Der erste Brief des Paulus an die Korinther. Wuppertal: Brockhaus. (Wuppertaler Studienbibel NT.)

DU TOIT, AB (red) 1984. Handleiding by die Nuwe Testament Band V: Die Pauliniese briewe: Inleiding en teologie. Pretoria: NG Kerkboekhandel.

FASCHER, E 1975. Der erste Brief des Paulus an die Korinther. Erster Teil. Berlin: Evangelische Verlag. (Theologischer Handkommentar.)

GUTHRIE, D 1974. New Testament introduction. 3rd revised ed. London: InterVarsity.

LABUSCHAGNE, CJ 1970. De Bijbel en het probleem van de homofilie. Kerk en 
Theologie 21/1, 55-65.

LATEGAN, BC 1984a. 1 Korintiërs, in Du Toit 1984: 52-79.

LATEGAN, BC 1984b. Die Pauliniese etiek, in Du Toit 1984: 320-331.

LINDEMANN, A 1986. Die biblische Thoragebote und die Paulinische Ethik, in Schrage, (Hrsg), Studien zum Text und zur Ethik des NT: Festschrift zum 80. Geburtstag von Heinrich Greeven, 242-265. Berlin: De Gruyter.

LOUW, JP \& NIDA, EA (eds) 1988. Greek-English Lexicon of the New Testament based on semantic domains, Vol 1 \& 2. New York: UBS.

MINEAR, PS 1983. Christ and the congregation: 1 Corinthians 5-6. Review \& Expositor 80, 341-350.

PATTE, D 1984. Preaching Paul. Philadelphia: Fortress (Fortress resources for preaching.)

POP, FJ 1971. De eerste brief van Paulus aan de Corinthiërs. 2de druk. Nijkerk: Callenbach. (PNT.)

RICHARDSON, P 1983. Judgment in sexual matters in 1 Corinthians 6: 1-11. NT 25/1,37-58.

SANDERS, JT 1975. Ethics in the New Testament: Change and development. Philadelphia: Fortress.

SCHRAGE, W (Hrsg) 1986. Studien zum Text und zur Ethik des NT: Festschrift zum 80. Geburtstag von Heinrich Greeven. Berlin: De Gruyter.

UKLEJA, PM 1983. Homosexuality in the New Testament. Bibliotheca Sacra 140/560 Oct - Dec, 350-358.

VAN AARDE, AG 1986. Demonologie in die Nuwe- Testamentiese tydvak. HTS 42, 547-563.

WEISS, J 1925. Der erste Korintherbrief. 10. Aufl. Göttingen: Vandenhoeck. (Meyer.)

WENDLAND, H 1970. Ethik des Neuen Testaments: Eine Einführung. Göttingen: Vandenhoeck.

WRIGHT, DF 1984. Homosexuals or prostitutes? The meaning of (\&pб€vokoital) (1 Cor. 6: 9, 1 Tim. 1-10). Vigiliae Christianae 38, 125-153. 